\title{
Development of Educative Snake Media to Improve Career Planning Ability Through Group Counselling
}

\author{
Marfuatun $^{1 *}$, Dewi Yulianti ${ }^{2}$, and Muhammad Sajidin ${ }^{3}$ \\ ${ }^{123}$ Universitas Hamzanwadi, Lombok Indonesia \\ *Corresponding Author: marfuatun.bkhamzanwadi@gmail.com
}

\begin{abstract}
This research produced a product in the form of educational ladder snake media which is useful and will be used by BK Madrasah Tsanawiyah Teacher, Nahdlatul Wathan No. 1 Talun, the main target of using this media to improve students' career planning skills. This type of research is Development which consists of 5 stages. Research subjects were limited to class IX-C students. for due diligence, the product is validated by 1 expert in guidance and counseling material and 1 expert in learning media. from the results of the material expert test that the results of the analysis of the validity of the material experts get a percentage of $93.8 \%$, based on the conversion level of the achievement of the validity of the material, the material in the media is categorized as very valid and feasible to use, whereas from the results of the analysis of the validity of the media experts get a percentage of $93.3 \%$, based on the conversion level of achievement of media validity, the media is categorized as very valid and feasible to use, next from the results of practicality data analysis, counseling guidance teacher responses get a percentage value of $93.3 \%$, based on criteria practicality, the media is categorized as very practical and feasible to use.
\end{abstract}

Keywords: Snake Media, Career Planning Skills, Counseling Guidance

\section{INTRODUCTION}

Education is a directed child socialization process. In essence, education as a process of applying normative science, the school environment plays a role including teachers in development. child psychosocial processes, namely changes in aspects of feelings, emotions, and personality of individuals as well as the way they relate to other people. in addition, education is an organized direction in shaping the personality, expertise and character of children.

Counselors as educators can not be separated from Article 1 paragraph (1) of the Act. No. 20 of 2003 concerning National Education which states that "education is a conscious and planned effort to create an atmosphere of learning and learning process so that students actively develop their potential to have spiritual spiritual power, self-control, personality, noble moral intelligence and skills needed by himself, the nation's people and the State. so that students' awareness is required to think about the importance of education for survival in order to achieve prosperity in the world and the hereafter ". Guidance and counseling services are important aspects of the school system. Counseling services are not just for students who are involved in disciplinary issues, but also for the positive development of individuals[1].

One of the development tasks that must be carried out by an individual is determining a career for the future. students should choose, plan, and decide their career based on the student's own decision, which is based on self ability, support the surrounding environment, and the prospects of work that exist in the community environment, but the success of the right student career is not as easy as that imagined. career is a series of jobs, positions, and positions held by someone in his life, but there are still students who think about their career, school goals, and future. for achieving the goals of the school itself it is necessary to plan career from the beginning, so students are ready to pursue the career that they expect. Career planning itself is inseparable from how students can recognize and choose a profession and find out the obstacles in the selection of professions related to the next study. Career 
planning programs need to begin at the junior high level and that junior high students need to be involved in career program planning and future needs assessments[2]. School counsellors may become more proactive by providing instruction and support for parents on how to help their child with career planning, developing relationships with students, and integrating community services into junior high career planning[3]

Based on observations and information from school counselors and subject teachers, as well as students in grades VIII and IX MTs. NW No. 1 Talun, the researcher obtained information through interview techniques that $80 \%$ of students still lacked the knowledge of the desired profession and were still confused with their career planning. by not having proper career planning, of course it will affect the selection of his career in the future. through group counseling services that are packaged in an educational snakes and ladders game is expected to improve the ability of students and other parties in career planning. this is due to group counseling using educative ladder snake media in improving student career planning can be easier. Because the snake ladder media is designed as attractive as possible, it is easier to understand so that it helps students improve career planning.

Based on these studies, researchers assume that media development is very important in helping School counselors in carrying out their duties and responsibilities and does not rule out the possibility of educational ladder snake media will be successfully used as an alternative media in guidance and counseling to be used by School counselors as a medium to help students solve problems related to career planning. referring to the real description of what happened then the core problem in this research and development is the absence of material or media as a source of learning for School counselors so that this research aims to develop a product in the form of snakes and ladders media education that can be used by School counselors in delivering material on career planning that is packaged in group counseling activities, and hopes that after this media is used by School counselors in group counseling activities, planning on student careers will further enhance ,besides being able to be a measuring tool to measure School counsellors skills in implementing group counseling services using snakes and ladders educational media .
Career plan needs to be done early by each individual so that they have the ability to understand information about themselves, information about career goals and realistic reasoning in understanding their own information and career goals[4]. Career planning is to identify troublesome beliefs you might have about making career decisions and searching for jobs[5][6]. Career planning is the process of setting career objectives and determining how to accomplish them[7]. Career development is intentional career planning and should be viewed as a critical and deliberate life process involving both the individual, it provides individuals with choices about career[8]. In the era of career transition, to have a positive orientation and knowledge about the factors that support a successful career planning is vital [9]. Human resource is the core issue of socio-economic development all over the world and human resource practice can serve as a sustainable competitive advantage, which are considered central in the company's performance[10]. The aim of professional career planning skills development is to motivate a personality to improve the professional activity and to develop the personal professional self-expression[11]. As the first step to choosing a career, your child should assess his or her interests, skills, abilities and work value [12]. It is extremely important that individuals acquire career planning skills and adopt a rational approach to solving career problems and making career decisions[13]. Career planning thus becomes an ongoing, lifelong process, of which you are in control[14][15]. Counselor helped him discover a preference for hand-on work, motivating and leading other, and organising information or materials[16].

\section{METHOD}

In this research, the product developed was educative ladder snake media for class IX students of SMP / MTs. This study uses a research and development approach that adopts the Borg and Gall development model. This research and development is only limited to the feasibility test, based on the existing conditions and conditions, the researcher modifies this research and development stage by only using five stages, namely: (1) research and data collection; (2) planning; (3) draft development product; (4) small group trials; and (5) improvement or revision of the final product. The purpose of this research and 
development is to produce products in the form of educational ladder snake media that meet the acceptability criteria.

The instruments used in this study include interview guidelines, assessment questionnaires. interview guidelines are used to find out and collect preliminary data about the state of students and what is needed by the School counsellors in relation to student career planning problems. assessment questionnaire from experts on guidance and counseling materials, instructional media experts, School counselors and students of class IX C Madrasah Tsanawiyah Nahdlatul Wathan No. 1 Talun is useful to know the feasibility of the product in the form of educative ladder snake media is acceptable.

Interpretation of product quality analysis with valid criteria using conversions as in table 1 below:

Table 1. Conversion Achievement Level of Validity

\begin{tabular}{|l|l|}
\hline Validity criteria & Level of validity \\
\hline $85,01 \%-100,00 \%$ & Very valid \\
\hline $70,01 \%-85,00 \%$ & Quite valid \\
\hline $50,01 \%-70,00 \%$ & Low valid \\
\hline $01,00 \%-50,00 \%$ & Invalid \\
\hline
\end{tabular}

If the results of the validity analysis get a percentage of at least $70.01 \%$ in the "quite valid" category, or more than the same as $85.01 \%$ in the "very valid" category.

\section{RESULT AND DISCUSSION}

Material expert test results data in this case the assessment was given by 1 expert counseling material expert, as follows:

1. Media Validity Test

a. Material Expert Validity

Table 2. Material Expert Validity

\begin{tabular}{|c|c|c|c|c|c|c|}
\hline \multirow{2}{*}{ No. } & \multirow{2}{*}{ COMPONENT } & \multicolumn{5}{|c|}{ ASSESSMENT } \\
\hline & & 1 & 2 & 3 & 4 & 5 \\
\hline 1. & Suitability of content with basic competencies & & & & & $\sqrt{ }$ \\
\hline 2. & Suitability of indicators and learning objectives & & & & & $\sqrt{ }$ \\
\hline 3. & Suitability of the concept of material with student needs & & & & & $\sqrt{ }$ \\
\hline 4. & Material clarity & & & & $\sqrt{ }$ & \\
\hline 5. & Level of difficulty of the material & & & & $\sqrt{ }$ & \\
\hline 6. & Coverage of the material & & & & & $\sqrt{7}$ \\
\hline 7. & Suitability between the use of media and content of the material & & & & & $\sqrt{ }$ \\
\hline 8. & Suitability of the image with the material and factual condition & & & & $\sqrt{ }$ & \\
\hline 9. & The ability of the material to stimulate students' motivation and curiosity & & & & & $\sqrt{ }$ \\
\hline 10. & Grammar in the instructions for the use of media & & & & $\sqrt{ }$ & \\
\hline 11. & The suitability of language with KBBI & & & & & $\sqrt{ }$ \\
\hline 12. & Material wrangling & & & & & $\sqrt{ }$ \\
\hline 13. & Form of presentation of the material & & & & & $\sqrt{ }$ \\
\hline & TOTAL & & & & 16 & 45 \\
\hline
\end{tabular}

The data of media validity assessment results by material experts in the table above were analyzed using descriptive analysis of the percentage with the formula: 


$$
\begin{aligned}
V_{-a h} & =\frac{T S e}{T S h} \times 100 \% \\
& =\frac{61}{65} \times 100 \% \\
& =93,8 \%
\end{aligned}
$$

From the results of the analysis of the validity of the material experts get a percentage of $93.8 \%$, based on the conversion rate of achieving the validity of the media in table 2 , the media is categorized as very valid and suitable for use.

\begin{tabular}{|c|c|c|c|c|c|c|}
\hline \multirow{2}{*}{ No. } & \multirow{2}{*}{ COMPONENT } & \multicolumn{5}{|c|}{ Assessment } \\
\hline & & 1 & 2 & 3 & 4 & 5 \\
\hline 1. & Appropriateness of media content & & & & & $\sqrt{ }$ \\
\hline 2. & Media format & & & & $\sqrt{ }$ & \\
\hline 3. & Language use & & & & $\sqrt{ }$ & \\
\hline 4. & Media simplicity & & & & & $\sqrt{ }$ \\
\hline 5. & Integration with material & & & & & $\sqrt{ }$ \\
\hline 6. & Emphasis on material & & & & & $\sqrt{ }$ \\
\hline & TOTAL & & & & 8 & 20 \\
\hline
\end{tabular}

b. Media Expert Validity

Table 3. Media Expert Validity

Data on the results of the assessment of media validity can be seen in the table above analyzed using descriptive analysis of the percentage with the formula:

$$
\begin{aligned}
V_{-a h} & =\frac{T S e}{\operatorname{TSh}} \times 100 \% \\
& =\frac{28}{30} \times 100 \% \\
& =93,3 \%
\end{aligned}
$$

From the results of the analysis of the validity of media experts get a percentage of $93.3 \%$, based on the conversion rate of achieving the validity of the media in

\begin{tabular}{|c|c|c|c|c|c|c|}
\hline \multirow{2}{*}{ No. } & \multirow{2}{*}{ Description } & \multicolumn{5}{|c|}{ Answer choices } \\
\hline & & 1 & 2 & 3 & 4 & 5 \\
\hline 1. & The accuracy of the contens of media matrial & & & & & $\sqrt{ }$ \\
\hline 2. & The clarity of media material content & & & & & $\sqrt{ }$ \\
\hline 3. & $\begin{array}{l}\text { The compatibility of media materials with the level of } \\
\text { students' thinking }\end{array}$ & & & & & $\sqrt{7}$ \\
\hline 4. & The design of media display & & & & $\sqrt{ }$ & \\
\hline 5. & The appearance of images on the media & & & & $\sqrt{ }$ & \\
\hline 6. & $\begin{array}{l}\text { The harmony of the color of the text with the images on the } \\
\text { media }\end{array}$ & & & & & $\sqrt{ }$ \\
\hline 7. & Determination images on media & & & & & $\sqrt{ }$ \\
\hline 8. & The placement of images on the media & & & & & $\sqrt{7}$ \\
\hline 9. & Easy of the use instruction & & & & $\sqrt{ }$ & \\
\hline & TOTAL & & & & 12 & 30 \\
\hline
\end{tabular}
table 3 , the media is categorized as very valid and feasible to use.

2. Data Practicality of Media

a. Counseling Guidance Teacher Response

Table 4. Counseling Guidance Teacher Response

The practicality data analysis is as follows.

$$
\begin{aligned}
V_{-p g} & =\frac{T S e}{T S h} \times 100 \% \\
& =\frac{42}{45} \times 100 \% \\
& =93,3 \%
\end{aligned}
$$


From the results of the practicality data analysis of the responses of counseling guidance teachers get a percentage of $93.3 \%$, based on the practicality criteria of the media in table 4 , the media are categorized as very practical and feasible to use.

b. Class IX-C Student responses

Table 5. Class IX-C Student responses

\begin{tabular}{|l|c|c|c|}
\hline No. & Total Students & $\begin{array}{c}\text { Average Achievement } \\
\text { criteria }\end{array}$ & Level of practicality \\
\hline 1. & 15 & $90,49 \%$ & Very Practical \\
\hline 2. & 6 & $81,55 \%$ & Quite Practical \\
\hline 3. & 1 & $53,60 \%$ & Less Practical \\
\hline 4. & 1 & $46,40 \%$ & Not practical \\
\hline
\end{tabular}

Based on the table above, it was found that $90,49 \%$ of the percentage of students showed a very practical category of 15 people and practical as many as 6 people, while 2 students showed the categories of less practical and impractical. from the results above, it can be concluded that the media are considered very practical.

3. Media Interest Data

Table 6. Media Interest Data

\begin{tabular}{|l|c|c|c|}
\hline No. & Total Students & $\begin{array}{c}\text { Average Achievement } \\
\text { criteria }\end{array}$ & Level of attractiveness \\
\hline 1. & 17 & $90,44 \%$ & Very Interesting \\
\hline 2. & 4 & $83,33 \%$ & Quite Interesting \\
\hline 3. & 2 & $50,00 \%$ & Not Interesting \\
\hline
\end{tabular}

Based on the above table, 17 students got a average

4. Data Effectiveness Of The Media score of $90,44 \%$ so that the media was considered very interesting.

Table 7. Data Effectiveness Of The Media

\begin{tabular}{|l|c|c|c|}
\hline No. & Total Students & $\begin{array}{c}\text { Average Achievement } \\
\text { criteria }\end{array}$ & Level of effectiveness \\
\hline 1. & 5 & $91,25 \%$ & Very Active \\
\hline 2. & 16 & $78,13 \%$ & Active \\
\hline 3. & 2 & $62,50 \%$ & Less Active \\
\hline
\end{tabular}

Based on the table above, it was found that 16 students showed active and 5 students showed very active categories using educational snakes and ladders, giving questions about careers, answering questions about careers and explaining the meaning of each plot content in the media, thus the media are considered effective.

\section{CONCLUSION}

Based on the results of the research that has been done, it can be concluded that this research and development produces a product in the form of educative ladder snake media to improve the career planning abilities of class IX-C MTs students. NW No. 1 Talun, the resulting media can be said to be feasible to be used as material for the implementation of guidance and counseling with several revisions according to the advice and input from validator material experts and media display experts as well as from guidance counseling teacher users and class IX-C students ,knowledge and planning about the career of class IX-C students can be said to be increased seen from the end of the process of using media which shows that media is very effective in improving career planning skills. 


\section{REFERENCES}

[1] S. Amat, "Guidance and Counselling in Schools," in 3rd International Conference on Current Issues in Education (ICCIE 2018), 2019.

[2] A. D. Bardick, K. B. Bernes, K. C. Magnusson, and K. D. Witko, "Junior high school students' career plans for the future: A Canadian perspective," J. Career Dev., vol. 32, no. 3, pp. 250-271, 2006.

[3] A. D. Bardick, K. B. Bernes, K. C. Magnusson, and K. D. Witko, "Junior high career planning: What students want," Can. J. Couns. Psychother. Can. Couns. psychothérapie, vol. 38, no. 2, 2004.

[4] R. Hariko and T. M. Anggriana, "Reviewing the role of families in student career planning," Konselor, vol. 8, no. 1, pp. 6-11, 2019.

[5] J. D. Krumboltz, "Private Rules in Career Decision Making. Special Publications Series No. 38.," 1983.

[6] R. D. Lock, Taking Charge of Your Career Direction: Career Planning Guide, no. bk. 1. Cengage Learning, 2004.

[7] R. N. Lussier, Management Fundamentals: Concepts, Applications, and Skill Development. SAGE Publications, Incorporated, 2016.

[8] B. L. Marquis and C. J. Huston, Leadership Roles and Management Functions in Nursing: Theory and Application. Wolters Kluwer Health/Lippincott Williams \& Wilkins, 2009.

[9] T. Bharti and S. Rangnekar, "Giving off a Rosy
Glow: Exploring the Link Between Self-efficacy Optimism, Personal Optimism and Career Planning in Indian Sub-continent," in Transforming Organizations Through Flexible Systems Management, Springer, 2020, pp. 145162.

[10] H. Pham, "Impact of human resource management practices on enterprises' competitive advantages and business performance: Evidence from telecommunication industry," Manag. Sci. Lett., vol. 10, no. 4, pp. 721-732, 2020.

[11] A. Weintrit and T. Neumann, Marine Navigation and Safety of Sea Transportation: STCW, Maritime Education and Training (MET), Human Resources and Crew Manning, Maritime Policy, Logistics and Economic Matters. CRC Press, 2013.

[12] S. L. Jones and M. B. Harris, The Parent's Crash Course in Career Planning: Helping Your College Student Succeed. Career Dimensions, 2007.

[13] R. E. Hess, Career Stress in Changing Times. Taylor \& Francis, 2014.

[14] B. Ball, "Manage your own career: A self-help guide to career choice and change," 1989.

[15] L. Sugarman, Life-span Development: Frameworks, Accounts and Strategies. Taylor \& Francis, 2004.

[16] F. Fabricant, J. Miller, and D. Stark, Creating Career Success: A Flexible Plan for the World of Work. Cengage Learning, 2014. 